\title{
IAMJ
}

INTERNATIONAL AYURVEDIC MEDICAL JOURNAL

\section{ROLE OF RASA DHATU IN THE MAINTENANCE OF BODY}

\author{
Anujaa D ${ }^{1}$, Rashmi B.V ${ }^{2}$, Rekha K.B.P ${ }^{3}$, Kalpana ${ }^{4}$ \\ ${ }^{1}$ II Year BAMS Scholar, Sri Dharmasthala Manjunatheshwara Institute of Ayurveda \& Hospital, Bangalore, \\ Karnataka, India \\ ${ }^{2}$ Assistant Professor, Department of Roga Nidana \& Vikruti Vijnana, Sri Dharmasthala Manjunatheshwara \\ Institute of Ayurveda \& Hospital, Bangalore, Karnataka, India \\ ${ }^{3}$ Associate Professor, Department of Roga Nidana \& Vikruti Vijnana, Sri Dharmasthala Manjunatheshwara \\ Institute of Ayurveda \& Hospital, Bangalore, Karnataka, India \\ ${ }^{4}$ HOD \& Professor, Department of Roga Nidana \& Vikruti Vijnana, Sri Dharmasthala Manjunatheshwara \\ Institute of Ayurveda \& Hospital, Bangalore, Karnataka, India
}

Corresponding Author: anujaadams@gmail.com

https://doi.org/10.46607/iamj3309122021

(Published Online: December 2021)

Open Access

(C) International Ayurvedic Medical Journal, India

Article Received: 24/11//2021 - Peer Reviewed: 05/12/2021 - Accepted for Publication 14/12/2021

\section{Check for updates}

\begin{abstract}
Ayurveda emphasizes on maintenance of health in a healthy individual and treating the diseased ones. The human body comprises Tridosha, Saptadhatu, Trimala (structural and functional entities of the body). Sharira (body) is a mula for health as well as disease. Srotas (body channels) are those channels that transport and transform the substances to respective tissues, cells of the human body required for life sustenance. As the Dhatu's are classified as Sthayi and Asthayi dhatu, based on the Aahara (food) consumed the respective Dosha Utpatti (biotransformation) takes place leading to Saara Kitta Vibhajana (formation of metabolic nutrients and waste). Rasa dhatu is an Asthayi Dhatu which is predominant of Jala Mahabhuta. From the Aahara Rasa, Rasa Dhatu is formed which is the prime Dhatu resulting in the development of subsequent dhatus of the sharira. Rasa Saara Purusha is endowed with Aayushmanta (longer life span) and Aarogya (health). As Rasadhatu Dusti Janya Vikaras are abundant in our clinics, understanding of Rasavaha Srotodusti Nidana (causative factor) and Lakshana (signs and
\end{abstract}


symptoms) in a patient with a relevant examination by means of Trividha Pariksha and prescribing appropriate Chikitsa (treatment) by understanding Guna-Karma principle is the need of the hour.

Keywords: Rasavaha Srotas (lymph channels), Pariksha (examination), Chikitsa (treatment)

\section{INTRODUCTION}

We all survive and entirely depend on the food we intake. This concept has been explained in Ayurveda. Acharya vaghbata ${ }^{1}$ and charaka ${ }^{2}$ have explained the three main pillars of life - Aahara (food), Nidra (sleep) and Brahmacharya (maintenance of abstinence). Ayurveda mainly emphasizes the "Saptadhatu" (seven tissues) concept. The Saptadhatus are Rasa (lymph), Rakta (blood), Mamsa (muscle), Meda (fat), Asthi (bones), Majja (bone marrow), and Shukra (semen) respectively. These can be correlated to the seven tissues and bodily systems according to contemporary science. Acharyasushruth ${ }^{3}$ has explained that the food we consume is of Panchamahabhuta (five basic elements such as air, water, wind, earth, and space). It has Shad rasas (six types of taste), Dviveerya (two kinds of potencies) and Anekaguna (the food is composed of various qualities). Due to the action of Jataraagni (digestive fire), the Aahara rasa (the essence of food) undergoes Pachana (digestion), the Paramasukshmabaga(minute) of Aahara rasa forms the first Dhatu i.e., the Rasa dhatu. Aacharya Charaka ${ }^{4}$ compares this, just like how fire placed below the vessel helps the food to cook, similarly, the Agni(fire) helps in Pachana karma. According to Sushrutha ${ }^{5}$, the main seat of Rasa dhatu is Hridaya (heart). The heart gives origin to the Rasa Dhamanee (vessels of lymph) in which the Rasa dhatu travels. These are twenty-four in number, ten of them carry the Rasa dhatu to the upper part of the body, the other ten carry the Rasa dhatu to the lower part of the body and the remaining four carry the Dhatu obliquely. Sushrutha ${ }^{6}$ calls the Rasa dhatu "Gativachakadhatu" (which means it moves throughout the body in a continuous manner). The Rasa dhatu is further divided into two types, they are- Sthayee rasa dhatu (stagnant lymph) and Poshaka rasa dhatu (circulating lymph). The Sthayee rasa dhatu is stagnant and can be compared to the interstitial fluid or tissue fluids. The
Poshaka rasa dhatu travels throughout the Shareera as mentioned earlier and it can be compared to the lymph.

Data source - A thorough review of Ayurvedic classical texts Charaka Vimana, Chraka sutra, physiology and pathology books, embryology, contemporary science books, relevant articles are cited for the present study.

\section{DISCUSSION}

\section{Karma of rasa dhatu}

Aacharya Vaghbata ${ }^{7}$ has mentioned the functions of the Saptadhatus and the primary function of the Rasa dhatu is Preenana (nourishment). Sushrutha ${ }^{8}$ attributes Tripti(satisfaction) and Prasannata (lusture) Karma (function) to the Rasa dhatu. He also states that Rasa dhatu helps in the nourishment of the succeeding Dhatu that is the Raktadhatu.

\section{Transformation rasa dhatu}

Aacharya charaka ${ }^{9}$ has explained the Ksheeradhadinyaya (law of transformation). According to this concept, the Purvadhatu (previous tissue) gets transformed into the Uttharotradhatu (preceding tissue) just like the analogy of transformation of entire Ksheera(milk) into Dadhi(curd), Dadhi into Navaneeta (butter) and butter into Ghrita(ghee). According to this theory, the Rasa dhatu is converted into Rakta(blood), the Rakta into Mamsa (muscle tissue) similarly the other Dhatus up to the Shukra$\operatorname{dhatu(semen)}$ is formed. The Ahara(food) which undergoes Parinama (changes such as digestion) gets converted to Aahararasa (the essence of food) by respective Avasthapaka (stages of digestion), thus forming Aahara rasa if converted to first Dhatu i.e., Rasa dhatu. When the Prasadabhaga of Aahara (essence portion of food) comes in contact with the Rasa Dhatwagni (digestive fire of the rasa dhatu), the Dhatu divides into two parts Sthula (major part) and Sukshmabhaga (minor part) namely. The Sthulabha- 
$g a$ is responsible for providing nutrition to the $R a$ sadhatu whereas the Sukshmabhaga is responsible for the formation of Upadhatu (sub-tissues) and the preceding Dhatu and also the Dhatumala (the excretory substance of dhatu). The quantity of Rasadhatu according to charaka ${ }^{10}$ is nine Anjalipramana. One Anjali can be taken as the total quantity measured when one joins their palms together. It differs from person to person. The circulation is mainly carried out by the Vyanavata (energy present in the heart) that is present in the Hrudaya(heart). The Vyanavata forcefully expels the Rasadhatu through the twenty-four $R a$ sadhamanee (rasa channels) present in the Hrudaya 11 .

\section{Upadhatu and dhatu mala}

Upadhatu is the entity that is very similar to the Dhatus these are the elements of the body that are not subjected to any transformation. They support the Dhatu, the Upadhatu of rasa are Aartava (menstrual flow) and Stanya (breast milk). Stanya (breast milk) is spread all over the body and on reaching the Stanas(breasts) it will be called the Stanya (breast milk). Rasadhatu gets matured and processed over a period of one month, and at the end of the month, the rasa gets converted into Shukra(semen) in men and Artava (menstrual flow) in women. Dhatu mala is the excretory product excreted by the dhatu when it undergoes Pacanakarma (the process of digestion). The Mala (a waste product) of Rasadhatu is Kapha (consist of water and earth elements), this is located mainly in the upper portion of the body i.e., chest and head, it is as well found in the major organs of our body such as the heart, lungs and the brain.

The Doshas and Dhatu undergo Dusti(vitiation) by means of Nidanasevana (etiological reasons) in both Rutu kriyakala(seasons) and Vyadhi kriyakala (stages of disease), which are understood by respective Vruddhi(increase), Kshaya(decrease), Pradoshajalakshanas (vitiated symptoms).

Dhatuvruddhi Lakshana (signs of increased rasa dhatu)

Rasadhatuvruddhi (increase in quality and work of rasa) Lakshana (signs and symptoms) - Utkleda in the Hrudayapradesha (the person will possess an unsta- ble mind) and Praseka (excessive salivation) $)^{12}$. The person may also experience a decrease in the digestive fire which leads to slow digestion, laziness, feeling of heaviness throughout the body can also be felt by the person. On examining, pallor will be elicited in the palms, lips, fingertips, tip and dorsum of the tongue. The person might also feel the excessive coldness as there is an increase in the qualities of $R a$ sadhatu among which coldness is one. There will be the presence of flaccidity of all the joints. Dyspnea and cough may be seen along with the other symptoms. Excessive sleep will also be an accompanying symptom because of the feeling of heaviness and laziness $^{13}$.

\section{Dhatukshaya Lakshana (signs of decreased rasa dhatu)}

Rasadhatukshaya (decrease in quality and function) Lakshana (signs and symptoms)- pain in the cardiac region, which in turn leads to palpitation. Emptiness in the cardiac region and excessive thirst is also noticed $^{14}$. The majority of these symptoms are elicited in the cardiac region as the heart is the Srotomula (origin of channels) for the Rasadhatu. Some other features observed are dryness of the skin, excessive tiredness, dehydration, and intolerance to sound ${ }^{15}$. Due to excessive diminution of the rasa dhatu in the body, the person becomes restless and exhausted even with slight exertion will be observed ${ }^{16}$.

A person suffering from an increase in Rasadhatu will crave such foods and drinks that decrease the source, whereas the person suffering from a decrease in Rasadhatu will crave the food articles that will increase the source. For example, when there is $R a$ sadhatu decrease in a person, he craves food items such as milk, whereas if there is rasa dhatu increase, he will dislike food items such as milk.

\section{Rasadushtilakshana (diseases formed due to vitia- tion of rasa dhatu)}

Diseases formed due to contamination of Rasadhatu are

Ashraddha (lack of interest in the food), Aruchi (tastelessness), Aasyavairasya (feeling of weird tastes in the mouth), Arasagnata (failure to identify any taste), Hrullasa (watering of mouth, excessive saliva- 
tion, nausea), Gourava (heaviness), Tandra (drowsiness), Angamarda (pain in body parts), Jwara (fever), Tama (feeling of darkness before the eyes), Pandutva (anaemia), Srotorodha (block in multiple channels of the body), Klaibya (impotence), Saada (fatigue, stoppage of working of organs and tissues), Krushangataa (emaciation), Nashoagnehe (destruction of agni, the metabolic fire), AyathakalaVali (premature wrinkling of skin), AyathakalaPalita (premature greying of hairs), Trupti (saturation) ${ }^{17}$.

Srotodushtikarana and lakshana (reason for vitiation and symptoms)

The reasons for the vitiation of the Rasavahasrotas are the excessive consumption of Guru(heavy), Sheeta(cold), Ati snigdha yukta ahara (excessive unctuous food) and also Achintana (no worrying) for things that need no Chintana(worry) ${ }^{18}$. The features of Dustarasadhatu (vitiated rasa) are Shosha(emaciation) and the diseases that arise due to the vitiation of Pranavahasrotas (channels of the respiratory system). The ultimate sign might be dead as well. Here, the channels of the respiratory system are majorly involved as the origin of the channels for Rasadhatu is the heart which is also the location for life ${ }^{19}$. There are some diseases that are caused by the vitiation of rasa dhatu either it may be due to Vruddhi(increase) or Kshaya(decrease). These are dislikings to food, anorexia, abnormal taste in the mouth, nausea, heaviness in the body, drowsiness, fever, fainting, asthenia, emaciation, anemia, premature greying of hairs, etc.

The vitiated Rasa dhatulakshanas (symptoms) can be seen as premonitory symptoms, symptoms, and complications in other diseases that manifest in the body.

\begin{tabular}{|c|c|c|c|}
\hline Vyadhis & Charakasamhitha & Sushruthasamhitha & Ashtangahridaya \\
\hline $\begin{array}{l}\text { Jwara } \\
\text { (fever) }\end{array}$ & $\begin{array}{ll}\text { - } & \text { Gaurava(heaviness) } \\
\text { - } & \text { Klama (tiredness) } \\
\text { - } & \text { Nidra(sleep) } \\
\text { - } & \text { Shrama(exhaustion) } \\
\text { - } & \text { Alasya (laziness) }\end{array}$ & $\begin{array}{l}\text { - Shrama(exhaustion) } \\
\text { - } \quad \text { Gurutha(heaviness) } \\
\text { - } \quad \text { Sheeta(coldness) }\end{array}$ & \\
\hline $\begin{array}{l}\text { Pandu } \\
\text { (anemia) }\end{array}$ & $\begin{array}{ll}\text { - } & \text { Rauksya(dryness) } \\
\text { - } & \text { Shrama(exhaustion) } \\
\text { - } & \text { Hrudayaspandana(palpitation) } \\
\text { - } & \text { Shwasa (dyspneaon exertion) } \\
\text { - } & \text { Gaurava(heaviness) } \\
\text { - } & \text { Shosha(emaciation) } \\
\text { - } & \text { Kampa(tremors) } \\
\text { - } & \text { Nidraalu(sleep) } \\
\text { - } & \text { Kasa(cough) } \\
\text { - } & \text { Agnisaada (decreased Digestive } \\
& \text { fire) } \\
\text { - Hrudayaavapeedana (pain in cardi- } \\
\text { ac region) }\end{array}$ & $\begin{array}{l}\text { Shuklakshnam (whitish } \\
\text { discolouration of eyes) }\end{array}$ & \\
\hline $\begin{array}{l}\text { Hrudroga } \\
\text { (Heart prob- } \\
\text { lems) }\end{array}$ & $\begin{array}{l}\text { - } \quad \text { Kasa(cough), } \\
\text { - Shwasa(dyspnea), } \\
\text { - Hrutshoonya (feeling of emptiness in } \\
\text { heart), } \\
\text { - Shoosha(emaciation), } \\
\text { - } \text { Guruthva(heaviness), } \\
\text { - Praseka (excessive salivation), } \\
\text { - } \text { Kasa(cough) }\end{array}$ & $\begin{array}{l}\text { - Hrudayaklama (pain in } \\
\text { cardiac region) } \\
\text { - } \quad \text { Shoosha(emaciation) } \\
\text { - } \quad \text { Gaurava(heaviness) } \\
\text { - } \begin{array}{l}\text { Agnimaandya (decreased } \\
\text { digestion) }\end{array}\end{array}$ & \\
\hline
\end{tabular}




\begin{tabular}{|c|c|c|c|}
\hline & $\begin{array}{l}\text { - Hruthdaha (burning sensation in } \\
\text { heart region), } \\
\text { - Niddra sukham(sleep) } \\
\text { - Hrudayam suchivedana (pricking } \\
\text { type of pain in the cardiac region) }\end{array}$ & & \\
\hline $\begin{array}{l}\text { Shwayathu } \\
\text { (inflamma- } \\
\text { tion) }\end{array}$ & $\begin{array}{l}\text { - } \quad \text { Gaurava(heaviness), } \\
\text { - } \quad \text { Praseka (excess salivation), } \\
\text { - } \quad \text { Nidra(sleep), } \\
\text { - } \quad \text { Vahnimaandya (decreased digestion) }\end{array}$ & $\begin{array}{l}\text { - Shukla (whitish discol- } \\
\text { ouration, } \\
\text { - Sheetha(coldness) }\end{array}$ & \\
\hline $\begin{array}{l}\text { Kamala } \\
\text { (jaundice) }\end{array}$ & $\begin{array}{l}\text { - Shwethavarchas (whitish discoloura- } \\
\text { tion), } \\
\text { - Gurunahrudayena (heaviness of } \\
\text { heart), } \\
\text { - Alpaagni (decreased digestion), } \\
\text { - Shwaasa(dyspnea) }\end{array}$ & $\begin{array}{l}\text { - Agni saada (decreased } \\
\text { digestion), } \\
\text { - Hrudayaavapeedana } \\
\text { (pain in cardiac region) }\end{array}$ & $\begin{array}{l}\text { - Analabramsha (decreased } \\
\text { digestion) }\end{array}$ \\
\hline $\begin{array}{l}\text { Raktapitta } \\
\text { (Bleeding } \\
\text { disorders) }\end{array}$ & $\begin{array}{l}\text { - Shyaavaruna (whitish discoloura- } \\
\text { tion), } \\
\text { - } \quad \text { Rooksha(dryness) } \\
\text { - } \quad \text { Avipaka(indigestion), } \\
\text { - Shwasa(dysonea), } \\
\text { Kasa(cough) }\end{array}$ & $\begin{array}{l}\text { - Sheetakamitva (attracted } \\
\text { to cold), } \\
\text { - } \quad \text { Kasa(cough), } \\
\text { - } \quad \text { Avipaka(indigestion), } \\
\text { Peedanainhrudaya } \\
\text { (pain in cardiac region) } \\
\text { - Sheetala(coldness) }\end{array}$ & \\
\hline $\begin{array}{l}\text { Vatarakta } \\
\text { (Gouty arthri- } \\
\text { tis) }\end{array}$ & $\begin{array}{l}\text { - } \quad \text { Shaitilya(looseness), } \\
\text { - } \quad \text { Gurutva(heaviness), } \\
\text { - } \quad \text { Shoukshya(roughness), } \\
\text { - } \quad \text { Shwaasa(dyspnea) }\end{array}$ & - Sheetatva(cold) & \\
\hline $\begin{array}{l}\text { Kushta } \\
\text { (Skin diseas- } \\
\text { es) }\end{array}$ & $\begin{array}{l}\text { - } \quad \text { Shrama(tiredness) } \\
\text { - } \quad \text { Gaurava(heaviness), } \\
\text { - } \quad \text { Shoosha(emaciation), } \\
\text { - } \quad \text { Raukshya(dryness), } \\
\text { - } \quad \text { Shwaitya (whitish discolouration), } \\
\text { - } \quad \text { Shaitya(coldness) }\end{array}$ & $\begin{array}{l}\text { - Parushya(roughness), } \\
\text { - } \quad \text { Gaurava(heaviness) }\end{array}$ & \\
\hline $\begin{array}{l}\text { Visarpa } \\
\text { (herpes) }\end{array}$ & $\begin{array}{l}\text { - Agnikshaya (reduced digestive pow- } \\
\text { er), } \\
\text { - } \quad \text { Gaurava(heaviness), } \\
\text { - } \quad \text { Sidra(sleep), } \\
\text { Shwetanakhanayanavadana (whitish } \\
\text { discolouration of nails, eyes and } \\
\text { mouth) }\end{array}$ & & - \\
\hline Galaganda & & & $\begin{array}{l}\text { - Shoosha(emaciation), } \\
\text { - Guru(heavy), sheethaspar- } \\
\text { sha (cold in touch) }\end{array}$ \\
\hline $\begin{array}{l}\text { Prameha } \\
\text { (diabities) }\end{array}$ & $\begin{array}{l}\text { - Shitilaanga (looseness of body } \\
\text { parts), } \\
\text { - Nidra(sleep), } \\
\text { - Rooksha(dryness), } \\
\text { - Avipaaka(indigestion) }\end{array}$ & 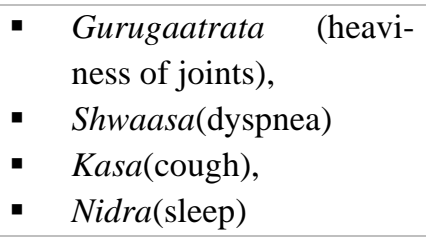 & \\
\hline
\end{tabular}




\begin{tabular}{|l|l|l|l|}
\hline Vatavyadhi & - Shoosha(emaciation), & & \\
& - Nidra(sleep) & & \\
Kalibya & - Shwasa(dyspnea), & & \\
(Male infertil- & - Swinnagatra (looseness of joints), & & \\
ity) & - Hruthroga (heart disease), & & \\
& - Shrama(exhaustion), & & \\
\hline $\begin{array}{l}\text { Rajayakshma } \\
\text { (tuberculosis) }\end{array}$ & - Kasa(cough) & - Kasa(cough), & \\
\hline $\begin{array}{l}\text { Chardi } \\
\text { (vomiting) }\end{array}$ & - Kasa(cough) & \\
& - Shwasa(dyspnea) & Praseka (excess saliva- & \\
\hline
\end{tabular}

Pareeksha: One of the main key features for diagnosing a disease properly is the Pareeksha(examination), the three main approaches according to Ayurveda are Pratyaksha (inspection examinations), Anumana (examination through inference) and Aptopadesha (examination through classical textbooks of Ayurveda).
Pratyakshapareeksha can be elicited by the Panchendriyas (five sense organs) which are Srotrendriya (sense of hearing), Sparshanendriya (sense of touch), Chakshurindriya (sense of vision), Rasanendriya (sense of taste), Ghranendriya (sense of smell).

\begin{tabular}{|c|c|}
\hline Pareeksha (examination aspect) & Bhavas (symptoms elicited) \\
\hline $\begin{array}{l}\text { Pratyakshapareeksha (examination } \\
\text { by inspection) }\end{array}$ & 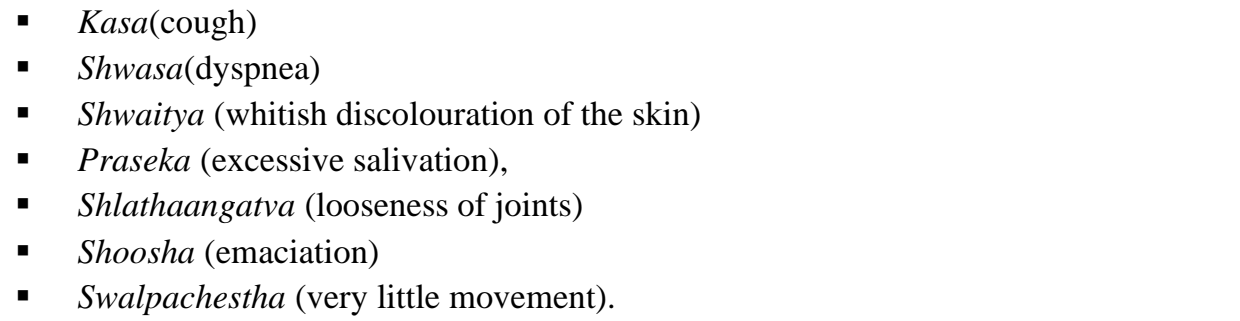 \\
\hline $\begin{array}{l}\text { Anumanapareeksha (examination } \\
\text { by inference) }\end{array}$ & $\begin{array}{l}\text { - Digestive power can be inferred by analyzing the Agni (digestive fire), } \\
\text { - strength of a person tells us about the ability to perform the exercise, } \\
\text { Upashaya (relieving factor) and Anupashaya (aggravating factor) infer the } \\
\text { knowledge about the hidden Lakshanas. }\end{array}$ \\
\hline $\begin{array}{l}\text { Aptopadeshapareeksha (history } \\
\text { taking) }\end{array}$ & $\begin{array}{l}\text { - } \text { Aggravating and relieving factors } \\
\text { - } \quad \text { Main Dosha for Vyadhiutapatti (origin of disease) } \\
\text { - Roga Arambhaka Hetu (mode of manifestation) } \\
\text { - Swabhava of Vyaadhi-mrudu or Daaruna (nature of disease-mild or severe) } \\
\text { - } \quad \text { Type of pain } \\
\text { - } \quad \text { Prognotoms by inspection } \\
\text { - } \text { Association of symptoms of increase, maintenance and reduction } \\
\text { - } \quad \text { Remanence of disease } \\
\text { - } \quad \text { Analyzing and diagnosing the disease } \\
\text { Dos and don'ts concerning the disease and the patient's condition. }\end{array}$ \\
\hline
\end{tabular}

Rasadhatu Chikitsa: Analysis of Srotodushti Karanas and Lakshanas by means of Pariksha helps in arriving at an accurate diagnosis of a disease. Pre- scribing a Chikitsa (treatment protocol) which involves Aushadha (medicines), Aahara, Vihara (unwholesome food and activities) is the next step. 
Treatment is assessed based on the Guna and Karma are to be analyzed accordingly. principle. Hence Vimshati gunas (set of 20 qualities)

\begin{tabular}{|c|c|c|}
\hline Guna(quality) & Meaning & Example \\
\hline Guru (heaviness) & The one responsible for falling action & Wheat, curd \\
\hline Laghu(lightness) & The one responsible for weight loss & Puffed rice, green gram \\
\hline Sheeta(coldness) & They arrest movement and cause stagnation & Sandalwood, ice \\
\hline Ushna(hotness) & They generate sweating & Pepper, chilli \\
\hline Snigdha(unctuousness) & The one that can soak & Drumstick, ghee \\
\hline Ruksha(dryness) & It does dehydration and drying of the body & Horsegram \\
\hline Manda(dullness) & The quality that acts slowly & Amla, curd \\
\hline Teekshna(sharpness) & The one which has a quick action & Ginger, pepper \\
\hline Sthira(immobility) & It can support & Wheat, rice flakes \\
\hline Sara(mobility) & The one which has the property to flow & Bamboo, anthocephaluscadamba \\
\hline Mridu(softness) & Substances capable of loosening & Oil, ghee \\
\hline Katina (hardness) & They strengthen the body & Coconut shell, conch shell \\
\hline Vishada (clearness) & Ability to wash and clean & Neem \\
\hline Picchila (sliminess) & The ability to coat/stick & Commiphora Mukul \\
\hline Shlakshana(smoothness) & Ability to heal as they promote the growth of new tissue & Turmeric \\
\hline Khara (roughness) & The one that has scrapping action & Drumstick \\
\hline Sukshma(minuteness) & Ability to penetrate & Alcohol, ghee \\
\hline Saandra(solidity) & Ability to clarify & Milk cream, butter \\
\hline Drava(fluidity) & The ability to dissolve substances & Water \\
\hline
\end{tabular}

The treatment for Rasadhatu is Langhana (reducing therapy) they are often forms. It can be divided into two types namely Shodhana (purificatory treatment) and Shamana (palliative measures). Shodana(purification) are of four types, they are $\mathrm{Va}$ mana(emesis), Virechana(purgation), Asthapana vasti (enema), Anuvasanavasti(enema), Nasya (nasal administration). Shamana (palliative medicines) can be of the following types, Deepana(digestants), $\mathrm{Pa}$ chana(carminatives), Kshuth (hunger), Trush$n a$ (thirst), Aatapa (exposure to sunlight), Vyayama (exercise), Marutasevana (exposure to air). These therapies can be efficient only with the use of potent drugs that are enlisted in the Dashaiemani (group of ten) drugs. They are Deepaneeya Mahakashaya, Trushnanigrahaneeya Mahakashaya, Vamanopaga Mahakashaya, Virechanopaga Mahakashaya, Asthapananopaga Mahakashaya, Anuvasanopaga Mahakashaya according to charaka and Pippalyaadigana, Patolyadigana, Kakolyadigana, Nyagrodhaadigana, Mustadigana according to Sushrutha. The common drugs from these dashemaani are-
Musta (Cyperus rotundus)

Parpataka (Fumaria parvifolia)

Chandana (Santalum album)

Madhu (Glycyrrhiza glabra)

Sadapushpa (Catharanthus roseus)

Draksha (Vitis vinifera)

Parushaka (Grewia asiatica)

Badara (Ziziphus mauritiana)

Vibhitaka (Terminalia bellirica)

Amalaka (Emblica officinalis)

Trivrut (Operculina turpethum)

Madanaphala (Randia dumatorun)

Shatapushpa (Pimpinella anisum)

Rasna (Alpinia calcarata)

Punarnava (Boerhvia diffusa)

Agnimantha (Premna integrifolia)

Shyonaka (Oroxylum indicum)

\section{Vyayama}

Importance and the methods of practising Vayama (physical activities for maintenance of healthy mind and body). Acharya Charaka states that Vyayama mitigates Kapha dosha in our body and increases 
Vata and Pitta (guna and karma). Vyayama helps to mobilize Kapha and relaxes the joints and relieves stiffness. Vyayama is that activity that makes the body Sthira (stable) and Balavan(strong) on doing according to one's ability ${ }^{20}$. The lightness of the body increases the ability and strength of the body for doing physical activities, the body becomes more stable, ability to endure more stress, decreases the Prakupita Doshas, increases digestive power. Acharya Vagbhata opines those exercises are the activities that produce tiredness in the body resulting in the lightness of the body, ability to perform normal routine activities with enthusiasm, increasing the Aahara Shakti (digestive power), reducing fat and body parts become distinct and firm ${ }^{21}$. Strong people are those who are habituated to take unctuous food, and in cold seasons one should do exercises half their capacity. It is done lesser in the case of Greeshma (summer), Varsha (rainy), Sharad (Autumn) Rutus (seasons).

\section{CONCLUSION}

In the present study, an effort is made in understanding the Rasavaha Sroto pathology, analysis of diagnostic protocol concerning Chikitsa.

- Rasavahasroto Vikaras are Bahya (external) and Aabhyantara Rogamargaja (internal route) Vyadhi's, the mode of manifestation of Vikara (disease) is at the Srotomula Sthana or in the Sroto Marga.

- Examination of Rasavaha Srotas to be emphasized on Trividha Pariksha (Pratyaksha, Anumana, Aaptopadesha Bhavas)

- Based on the Guna - Karma principle, Chikitsa is to be framed accordingly as Pathya (Langhana Krama), Aushadha, Vihara (Vyayama).

- Assessment of Agreyadravya concerning Chikitsa

\section{REFERENCES}

1. Dr. Vidyanath, Astanga Hrdaya of Acharya Vagbhata, edited by Prof.R.H. Singh. Sutra Sthana, Ch.17, Ver.52, Chaukamba Surbharati Prakashan Varanasi, 2013, Pg. 147.

2. Agnivesha, Charaka samhita of Acharya Charaka, Dridhabala, edited by Vaidya Jadavaji Trikamji
Acharya. Sutra Sthana, Ch.11, Ver.35, Chaukamba Orientalia Varanasi, 2015, Pg.74

3. P.V. Sharma, Sushruta Samhita of Acharya Sushruta, Sri Dalhanacharya, edited by Jadavji Trikamji Acharya. Sutra Sthana, Ch.14, Ver.3, Chaukamba Orientalia Varanasi, 2014, Pg.59

4. Agnivesha, Charaka samhita of Acharya Charaka, Dridhabala, edited by Vaidya Jadavaji Trikamji Acharya. chikitsa Sthana, Ch.15, Ver.8, Chaukamba Orientalia Varanasi, 2015, Pg.512

5. P.V. Sharma, Sushruta Samhita of Acharya Sushruta, Sri Dalhanacharya, edited by Jadavji Trikamji Acharya. Sutra Sthana, Ch.14, Ver.3, Chaukamba Orientalia Varanasi, 2014, Pg.59

6. P.V. Sharma, Sushruta Samhita of Acharya Sushruta, Sri Dalhanacharya, edited by Jadavji Trikamji Acharya. Sutra Sthana, Ch.14, Ver.13, Chaukamba Orientalia Varanasi, 2014, Pg.62

7. Dr. Vidyanath, Astanga Hrdaya of Acharya Vagbhata, edited by Prof.R.H. Singh. Sutra Sthana, Ch.11, Ver.4, Chaukamba Surbharati Prakashan Varanasi, 2013, Pg.188.

8. P.V. Sharma, Sushruta Samhita of Acharya Sushruta, Sri Dalhanacharya, edited by Jadavji Trikamji Acharya. Sutra Sthana, Ch.15, Ver.5, Chaukamba Orientalia Varanasi, 2014, Pg.68

9. Agnivesha, Charaka samhita of Acharya Charaka, Dridhabala, edited by Vaidya Jadavaji Trikamji Acharya. chikitsa Sthana, Ch.15, Ver.16-19, Chaukamba Orientalia Varanasi, 2015, Pg.514, 515

10. Agnivesha, Charaka samhita of Acharya Charaka, Dridhabala, edited by Vaidya Jadavaji Trikamji Acharya. shaarera Sthana, Ch.7, Ver.15, Chaukamba Orientalia Varanasi, 2015, Pg.339

11. Agnivesha, Charaka samhita of Acharya Charaka, Dridhabala, edited by Vaidya Jadavaji Trikamji Acharya. chikitsa Sthana, Ch.15, Ver.36, Chaukamba Orientalia Varanasi, 2015, Pg.516

12. P.V. Sharma, Sushruta Samhita of Acharya Sushruta, Sri Dalhanacharya, edited by Jadavji Trikamji Acharya. Sutra Sthana, Ch.15, Ver.14, Chaukamba Orientalia Varanasi, 2014, Pg.70

13. Dr. Vidyanath, Astanga Hrdaya of Acharya Vagbhata, edited by Prof.R.H. Singh. Sutra Sthana, Ch.11, Ver.7, Chaukamba Surbharati Prakashan Varanasi, 2013, Pg.189.

14. P.V. Sharma, Sushruta Samhita of Acharya Sushruta, Sri Dalhanacharya, edited by Jadavji Trikamji Achar- 
ya. Sutra Sthana, Ch.15, Ver.14, Chaukamba Orientalia Varanasi, 2014, Pg.70

15. Dr. Vidyanath, Astanga Hrdaya of Acharya Vagbhata, edited by Prof.R.H. Singh. Sutra Sthana, Ch.11, Ver.17, Chaukamba Surbharati Prakashan Varanasi, 2013, Pg.191.

16. Agnivesha, Charaka samhita of Acharya Charaka, Dridhabala, edited by Vaidya Jadavaji Trikamji Acharya. sutra Sthana, Ch.17, Ver.64, Chaukamba Orientalia Varanasi, 2015, Pg.103

17. Agnivesha, Charaka samhita of Acharya Charaka, Dridhabala, edited by Vaidya Jadavaji Trikamji Acharya. Sutra Sthana, Ch.28, Ver.9-11, Chaukamba Orientalia Varanasi, 2015, Pg.179

18. Agnivesha, Charaka samhita of Acharya Charaka, Dridhabala, edited by Vaidya Jadavaji Trikamji Acharya. Vimana Sthana, Ch.5, Ver.13, Chaukamba Orientalia Varanasi, 2015, Pg.251

19. P.V. Sharma, Sushruta Samhita of Acharya Sushruta, Sri Dalhanacharya, edited by Jadavji Trikamji Acharya. Sutra Sthana, Ch.15, Ver.14, Chaukamba Orientalia Varanasi, 2014, Pg.70

20. Agnivesha, Charaka samhita of Acharya Charaka, Dridhabala, edited by Vaidya Jadavaji Trikamji Acharya. Sutra Sthana, Ch.7, Ver.31, Chaukamba Orientalia Varanasi, 2015, Pg.50

21. Dr. Vidyanath, Astanga Hrdaya of Acharya Vagbhata, edited by Prof.R.H. Singh. Sutra Sthana, Ch.2, Ver.10, Chaukamba Surbharati Prakashan Varanasi, 2013, Pg. 34

\section{Source of Support: Nil Conflict of Interest: None Declared}

How to cite this URL: Anujaa D et al: Role Of Rasa Dhatu In The Maintenance Of Body. International Ayurvedic Medical Journal \{online\} 2021 \{cited December 2021\} Available from:

http://www.iamj.in/posts/images/upload/3124_3132.pdf 